Brit. J. vener. Dis. (1964), 40, 254.

\title{
EARLY SYPHILIS IN A JAMAICAN PREVIOUSLY TREATED FOR CHILDHOOD YAWS*
}

BY

\author{
A. J. GILL AND S. M. LAIRD \\ St. Luke's Clinic, Manchester
}

Epidemiological evidence indicates that the incidence of syphilis is low in regions where yaws is endemic and that an attack of yaws confers protection subsequently against infection with syphilis. With the control achieved by mass anti-yaws campaigns, using penicillin, the extent of the disease has been greatly diminished and in some areas, where yaws was formerly endemic, it has been completely eradicated.

Curd (1963) reported that yaws had been almost completely eradicated from the Fiji Islands but that an increase in the number of cases of syphilis followed. On the other hand, Hackett (1953) stated that, in the areas of Nigeria and the Gold Coast where yaws once flourished but was now greatly on the decline, there had been no increase in the numbers of observed cases of syphilis.

If, in fact, an increase of syphilis does follow the eradication of yaws, it is an interesting question whether there is a cause and effect relationship between these two events. There has been a recent increase in early syphilis in many countries in which yaws cannot occur. The evidence regarding the immunity of a yaws patient to syphilis is largely equivocal. Charlouis (1881) successfully inoculated a patient with florid yaws with material from a penile chancre and produced secondary syphilis. Powell (1923) has described two cases and McKenzie (1924) and Carman (1935) one each in which patients with early yaws lesions acquired syphilis venereally. Hill (1953) saw two cases in the Gold Coast (Ghana) of old latent yaws which were successfully inoculated with $T$. pallidum and developed primary chancres. Hill believed that there is evidence of cross-immunity between the two diseases and that this is most marked in syphilis and in those cases of yaws in

* Received for publication June 8, 1964. which the duration of the active period or of the latency is long. Following upon this, if there is any truth in the cross-immunity theory, it should be shown in the later increased incidence of syphilis in the next generation of young adults who have been treated for active yaws as children and have thus been unable to develop immunity.

The following case, seen recently in Manchester, bears on this point and appears worthy of note.

\section{Case Report}

A single, male Jamaican, aged 23, was first seen in June, 1961, when he presented with a painful, right-sided inguinal bubo of 5 days' duration. There were no penile sores or scars. The man had lived as a child in a rural (yaws) area of Jamaica and gave a good history of childhood yaws which had been treated by injections. Some thickening and irregularity of both tibiae were noted clinically, with atrophic scarring of the overlying skin. Serological testing of the blood was reported to show negative Wassermann and Price's precipitation reactions and positive Reiter protein complementfixation and treponemal immobilization tests. Darkground examination, Frei, and lymphogranuloma venereum complement-fixation tests were all negative.

The lesions healed without trouble on sulphanilamide and streptomycin and the Wassermann and Price's precipitation reactions remained negative.

The patient was seen again in March, 1962, with balanitis, when these two tests were again negative. Between December, 1962, and December, 1963, he attended on many occasions with recurrent balanitis and inguinal adenitis which usually resolved on Sulphatriad or tetracycline. The Wassermann and Price reactions remained negative and repeated Frei and lymphogranuloma venereum complement-fixation tests were also negative.

In early December, 1963, he attended with indurated sores of the preputial margin and accompanying inguinal adenitis. Apart from his regular consort (coloured) there had been a single exposure to risk with an unknown 
white girl in Manchester, 6 weeks previously. Darkground examination was negative on a single occasion and before this could be repeated the patient was admitted to hospital. The Wassermann and Price's precipitation reactions were now reported positive (PPR titre 1 in 16, increasing to 1 in 1,024 within 10 days). The Reiter protein complement-fixation and treponemal immobilization ( 1 in 80$)$ tests were also positive.

A diagnosis of early secondary syphilis was made and treatment was begun. By February, 1964, after one course of weekly penicillin injections, the PPR titre had declined to 1 in 128, and another test in June showed a further decline to 1 in 32 .

The patient's coloured consort was traced and was also found to be suffering from secondary syphilis; there was no previous history of yaws in her case.

\section{Summary and Conclusion}

The case is described of a male West Indian who was treated for yaws in childhood in Jamaica and was found to have early venereal syphilis at the age of 25 years in Manchester. Reports of such cases have so far been rare, but are likely to become more numerous in the future as young adults from areas in which programmes for the childhood treatment and control of yaws have been successfully operated reach maturity without the immunity derived from non-venereal treponemal infection in childhood.

\section{REFERENCES}

Carman, J. A. (1935). Trans. roy. Soc. trop. Med. Hyg., 29, 261.

Charlouis, M. (1881). Vierteljahrsschr. Derm. Wien., $8,431$.

Curd, C. S. (1963). WHO Press release, Dec. 16.

Hackett, C. J. (1953). In "1st International Symposium on Yaws Control, Bangkok, 1952'”. Wld Hlth Org. Monogr. Ser. No. 15, pp. 129, 229.

Hill, K. R. (1953). Ibid., p. 107.

McKenzie, A. (1924). Lancet, 2, 1280.

Powell, A. (1923). Proc. roy. Soc. Med., 16, Sect. trop. Dis., p. 15.

Syphilis précoce chez un jamaiquain antérieurement traité pour pian infantile

\section{RÉSUMÉ}

On décrit le cas d'un antillais, qui fut traité pour le pian, pendant son enfance en Jamaïque, et chez qui, on trouva une syphilis vénérienne précoce à l'âge de 23 ans, à Manchester.

Jusqu'ici ces cas ont été rares, mais deviendront vraisemblablement plus nombreux dans l'avenir, au fur et à mesure que des jeunes venant de régions où le pian infantile a été traité et controlé avec succès, atteindront l'âge adulte, sans avoir acquis l'immunité dérivée d'une infection à tréponème non-vénérienne contractée pendant l'enfance. 